AperTO - Archivio Istituzionale Open Access dell'Università di Torino

Fluorophores in surface freshwaters: Importance, likely structures, and possible impacts of climate change

This is a pre print version of the following article:

Original Citation:

Availability:

This version is available http://hdl.handle.net/2318/1838133

since 2022-02-03T11:22:02Z

Published version:

DOI:10.1039/d1em00273b

Terms of use:

Open Access

Anyone can freely access the full text of works made available as "Open Access". Works made available under a Creative Commons license can be used according to the terms and conditions of said license. Use of all other works requires consent of the right holder (author or publisher) if not exempted from copyright protection by the applicable law. 


\title{
Fluorophores in surface freshwaters: Importance, likely structures, and possible impacts of climate change
}

\author{
Davide Vione,* Claudio Minero, Luca Carena \\ Dipartimento di Chimica, Università di Torino, Via P. Giuria 5, 10125 Torino, Italy. \\ *Corresponding author. Phone +39-011-6705296; E-mail: davide.vione@unito.it
}

\begin{abstract}
Fluorescence spectroscopy is one of the most useful techniques that are currently available for the characterisation of organic matter in natural water samples, because it combines easy availability of instrumentation, high sensitivity and limited requirements for sample treatment. The main fluorophores that can be found in natural waters are usually proteins (and/or free amino acids) and humic substances (humic and fulvic acids). The identification of these fluorescent compounds in water samples helps to obtain information about, among others, biological activity in the water body, possible transport of organic matter from soil, and the phenomenon of photobleaching that decreases both the absorbance and (usually) the fluorescence of natural organic matter. Interestingly, all these phenomena can be affected by climate change, which could alter to different extents the ratio between aquagenic and pedogenic fluorophores. Several events induced by warming in natural waters (and especially lake water) could enhance algal growth, thereby also enhancing the production of aquagenic organic matter. Intense precipitation events could increase the export of pedogenic material to surface waters, while photobleaching would be enhanced in the epilimnion of lakes when summer stratification becomes longer and more stable because of higher temperatures. Interestingly, photobleaching affects humic substances to a higher extent compared to protein-like material, thus protein fluorescence signals could be more preserved in stratified waters.
\end{abstract}




\section{Introduction}

\section{Absorption and fluorescence properties of natural waters}

In natural waters, the chromophoric dissolved organic matter (CDOM) is usually the main absorber of radiation. ${ }^{1-3}$ CDOM is the light-absorbing fraction of the dissolved organic matter (DOM), that is, the pool of organic compounds of mostly natural origin that are found in water and are small enough to pass through $0.45 \mu \mathrm{m}$ filter pores. These are operationally defined as "dissolved" in water. ${ }^{4}$ The absorption spectra of natural waters (and those of CDOM as a consequence) are usually not characterised by molecular bands. They rather show a featureless continuum, where absorbance decreases exponentially (or rather, quasi-exponentially) with increasing wavelength. ${ }^{\mathbf{5 6}}$ The nature of such absorption spectra has been the object of an intense scientific debate, ${ }^{7-11}$ a glimpse of which will be provided later on. Here it is only anticipated that the small variations of absorption from a pure mono-exponential form may have some significance. These variations can be highlighted by sequentially fitting parts of the absorption spectrum with an exponential function having a range of 10-20 nanometres, as opposed to the exponential fit of the whole spectrum or of large parts of it. ${ }^{\mathbf{1 2}}$ Interestingly, the wavelength trend of the spectral slopes thus obtained (which usually refer to the central wavelength of each fit interval) can be associated to the origin, nature and transformation of CDOM. ${ }^{12,13}$

As opposed to the feature-poor nature of the absorption spectra, the fluorescence spectra of natural waters show signals that are related to the occurrence of various fluorophores, which can be associated to organic material of different origin. ${ }^{\mathbf{1 4}}$ Proteins (as well as free amino acids) and humic substances (especially humic and fulvic acids) are the main fluorophores in surface water samples, and they are usually both observed in the same sample. Indeed, one needs a careful choice of the sampling environment to have some chance of obtaining a fluorescence spectrum of natural water that shows only one of these two features. ${ }^{15}$ Moreover, more uncommon fluorophores such as plankton pigments and fluorescent whitening agents of anthropic origin can also be detected in some samples. ${ }^{16,17}$

Differently from radiation absorption by chromophores, which plays a key environmental role in the transmission of radiation within the water column, fluorescence emission is only important as far as the characterisation of natural organic matter by spectroscopic techniques is concerned. ${ }^{\mathbf{1 8 , 1 9}}$ This review paper has the following goals: $(i)$ describe the fluorophores that occur in natural waters; (ii) make suggestions about their possible nature, as well as their importance in the study of organic matter, and (iii) report about the foreseen variations that the source materials might undergo in the future, in some predictable scenarios that are affected by climate change. 


\section{Principles of fluorescence emission}

Fluorescence emission is one of the possible processes that follow radiation absorption by a molecule. The vast majority of organic molecules has singlet ground states, where electrons are paired with anti-parallel spins in fully occupied orbitals. Radiation absorption can promote the molecule from the ground singlet state $\left(S_{0}\right)$ to an excited singlet state $\left(S_{1}, S_{2}, S_{3} \ldots S_{n}\right)$, where an electron reaches a molecular orbital with higher energy while maintaining the original spin orientation. The excited singlet-state configuration is characterised by two singly-occupied orbitals, while all the other orbitals are either fully occupied or empty. The excited electron is usually promoted from the ground vibrational level of $S_{0}$ to an excited vibrational level of the excited state $S_{n}$. The surplus vibrational energy within $S_{n}$ is then quickly lost, to reach the ground vibrational level of $S_{n}$. From there, several alternative (and competitive) processes may be operational: $(i)$ complete loss of the surplus energy by, e.g., internal conversion, after which the system gets back to $\mathrm{S}_{0}$ (in general, this is the most likely event); (ii) disexcitation from $\mathrm{S}_{\mathrm{n}}$ to $\mathrm{S}_{0}$ by emission of fluorescence radiation, which is a rare event if $n \neq 1$, and (iii) partial loss of energy, till the excited electron reaches the ground vibrational level of $S_{1}$. In this latter case, which is reasonably likely in several circumstances, additional processes can follow (apart from internal conversion, which is included in point (i) above): (a) Inter-system crossing to the first excited triplet state $\mathrm{T}_{1}$, which entails the inversion of the spin of the electron and is allowed by the fact that $T_{1}$ has lower energy than $S_{1}$. The $T_{1}$ state can then undergo internal conversion, chemical reactivity with other compounds that is sometimes very important, or emission of radiation by phosphorescence. (b) Emission of radiation $\left(\mathrm{S}_{1} \rightarrow \mathrm{S}_{0}\right)$, which constitutes the typical phenomenon of fluorescence. Fluorescence emission typically occurs from the ground vibrational level of $S_{1}$ to an excited vibrational level of $S_{0}$, and the surplus vibrational energy is again quickly lost. ${ }^{20,21}$

The various processes described above are depicted in the scheme reported in Figure 1. The different features of radiation absorption and fluorescence emission ensure that, in most cases, a molecule shows different absorption bands that correspond to the transitions $S_{0} \rightarrow S_{1}, S_{0} \rightarrow S_{2} \ldots$ $\mathrm{S}_{0} \rightarrow \mathrm{S}_{\mathrm{n}}$, but only one fluorescence band corresponding to $\mathrm{S}_{1} \rightarrow \mathrm{S}_{0}$ (Kasha's rule). ${ }^{20}$ Moreover, because vibrational energy is lost in several circumstances during the overall process, the energy of the photons emitted by fluorescence is lower (i.e., their wavelength is longer) than that of the absorbed photons. 


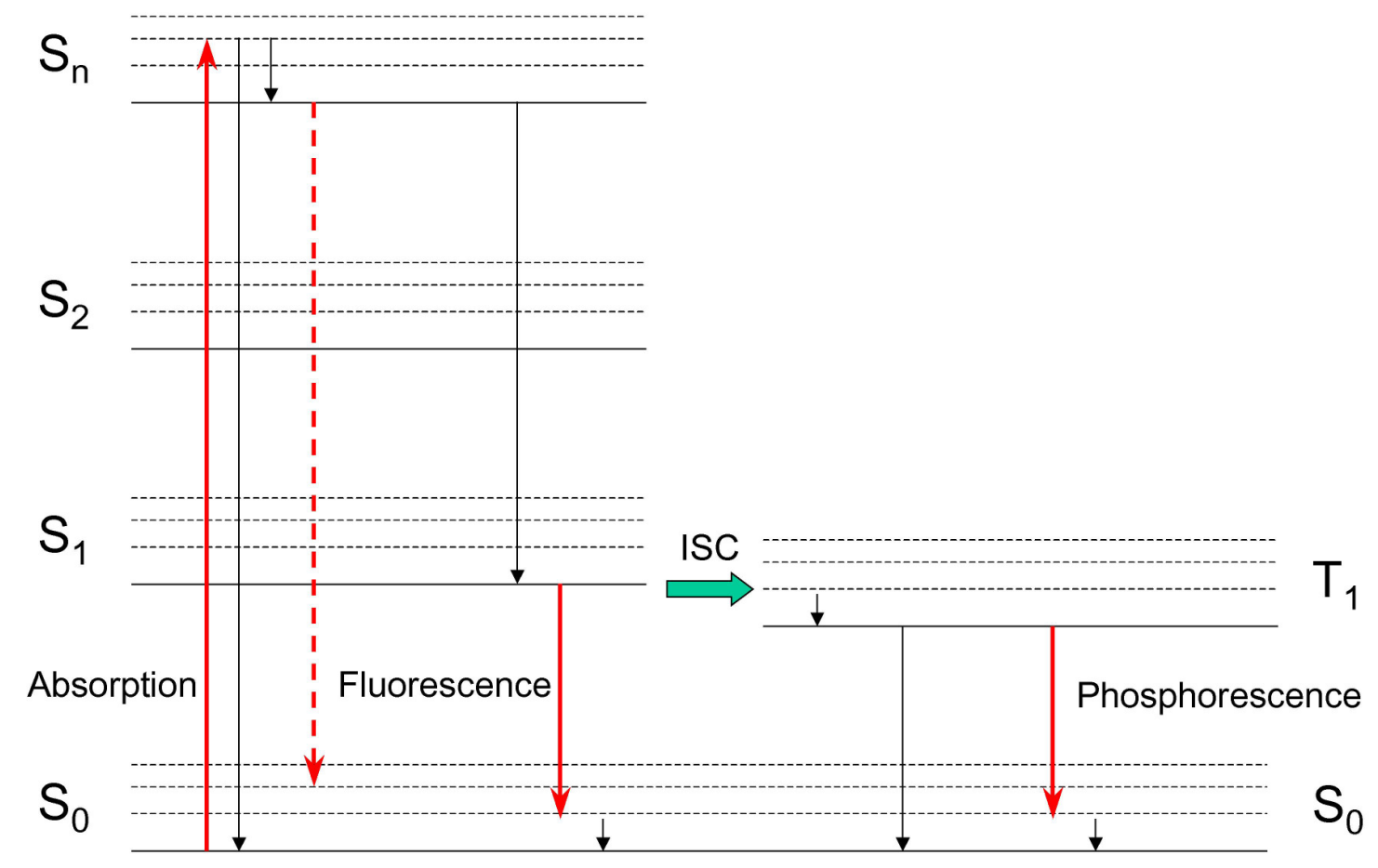

Figure 1. Schematic of the electron transitions that can follow the absorption of radiation by an organic molecule. The red arrows depict the processes involving radiation (either absorption or emission). The dashed arrow is intended to highlight the fact that fluorescence transitions from $S_{n}(n$ $>1)$ to $S_{0}$ are very rare. The black arrows represent loss of energy by non-radiative processes (internal conversion, vibrational deactivation, in some cases also chemical reactions). ISC = intersystem crossing.

\section{Fluorophores in natural waters: why they are important}

The environmental importance of fluorophores in fluorescent dissolved organic matter (FDOM) is not linked to their ability of emitting fluorescence radiation per se, which plays a negligible role in environmental processes, but rather to the fact that fluorescence spectroscopy enables the identification and characterisation of important species in surface-water samples. ${ }^{22}$ A possible point of view is that of seeing FDOM as a subset of CDOM, where the latter actually plays at least two key roles in natural surface waters: (i) By absorbing sunlight, CDOM affects the underwater light field and, therefore, the way radiation is transmitted into the water column. By shielding UVB radiation, CDOM protects aquatic organisms from its harmful effects. ${ }^{\mathbf{2 3 2}}$ On the other hand, very CDOM-rich waters are quite dark, which limits the penetration of photosynthetically active 
radiation (PAR) in the water column, and affects for instance the temperature and oxygenation of lake water during the summer season. Brownwater lakes have shallow epilimnia, and a large fraction of their water column may become anoxic during summer stratification. ${ }^{\mathbf{2 5 , 2 6}}$ (ii) Radiation absorption by CDOM triggers photochemical reactions, with production of reactive transient species (CDOM triplet states, ${ }^{3} \mathrm{CDOM}^{*}$; singlet oxygen ${ }^{1} \mathrm{O}_{2}$; hydroxyl radicals, ${ }^{\circ} \mathrm{OH}$ ) that induce the degradation of both natural compounds and man-made contaminants. ${ }^{27-30}$ As far as point $(i)$ is concerned, it is interesting to observe that photosynthetic organisms in CDOM-poor mountain lakes may avoid the UVB-rich water surface layer in favour of the sub-surface environment, while some zooplankton species carry out vertical migration to reach deeper water during daytime. Moreover, they may synthesise UV-absorbing pigments to be protected against short-wavelength radiation. ${ }^{24,31,32}$

Humic and fulvic acids are the most important sunlight-absorbing species that also emit fluorescence radiation and can thus be detected by fluorescence spectroscopy. ${ }^{33}$ On the other hand, proteins mostly absorb UVC radiation that does not occur in the environment but is used in spectroscopic measurements. Although proteins are definitely not the main UVC absorbers in water samples, their fluorescence emission under UVC excitation enables clear identification of their occurrence in a sample. ${ }^{\mathbf{1 4 , 3 4}}$ Therefore, the consideration of both absorption and fluorescence spectra provides a considerable amount of information about the nature of organic matter in water samples. $^{35}$

The ability of some water constituents to emit fluorescence radiation has been extensively exploited, especially in the application of fluorescence spectroscopy to the characterisation of natural waters. Fluorescence spectroscopy has several advantages that account for its wide use: ${ }^{\mathbf{3 6}}(i)$ little expensive instrumentation that is widely accessible; (ii) high sensitivity of the fluorescence technique, which enables direct and fast characterisation of water samples without complicated and time-consuming extraction/enrichment procedures, which might also introduce biases, and (iii) very large literature available on the subject, which provides a wide set of references and standards with which to compare one own's data. In particular, the so-called fluorescence matrix (or excitationemission matrix fluorescence spectroscopy, EEM) has become very popular as a characterisation tool. $^{36,37}$

A single fluorescence spectrum consists in the wavelength trend of the emission signals originating from single-wavelength excitation. In contrast, in a EEM spectrum one varies the excitation wavelengths sequentially in a wide range, while collecting each single fluorescence spectrum. The resulting 3D fluorescence matrix is usually provided in the form of a contour-plot, as shown for instance in Figure 2. 


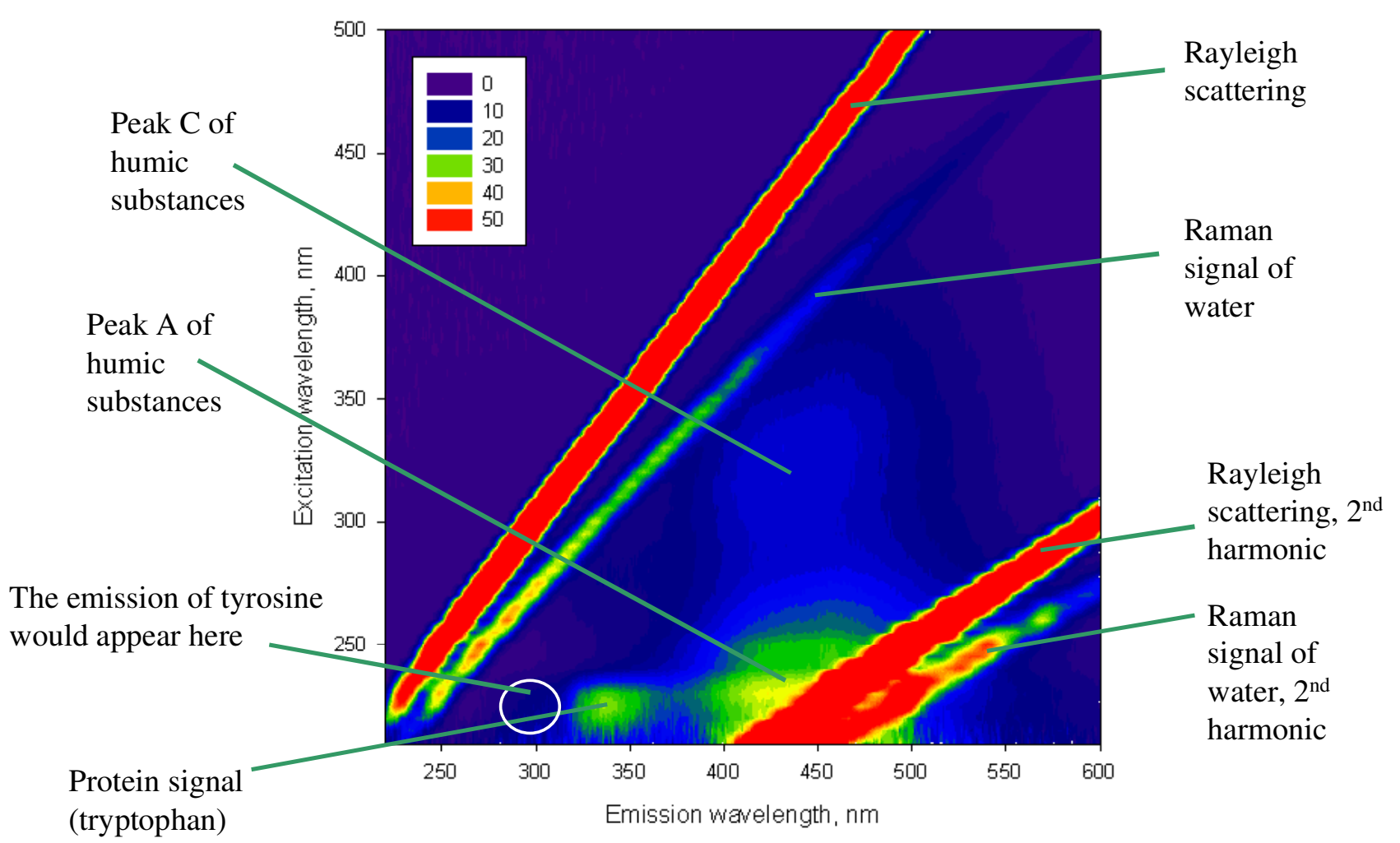

Figure 2. Example of a raw fluorescence EEM spectrum of a natural water sample. Note that Rayleigh scattering and the Raman signal of water are always observed in these spectra. The fluorescence signals suggest the occurrence of humic substances (peak A and peak C) and proteins (tryptophan signal, peak T). The position of other signals that could be seen in different EEM spectra (but not in this case) is also shown. The sample was taken from Lake Tre Becchi, located in the Western Italian Alps (Alpi Graie, Piedmont region, 2900 m a.s.1.) in June, 2013, soon after ice melting (Vione, unpublished data).

The different EEM traces give insight into the FDOM components occurring in the sample. The main FDOM fluorophores that can be identified in EEM spectra can be summarised as follows:

(a) Proteins and free amino acids. Among amino-acidic protein components, tyrosine and tryptophan are those showing the highest fluorescence emission. ${ }^{\mathbf{1 4}}$ Interestingly, both free and protein-bound tyrosine and tryptophan produce fluorescence signals located in the same region of the EEM spectrum (peak $\mathrm{B}$ for tyrosine, peak $\mathrm{T}$ for tryptophan), thus they can hardly be distinguished by fluorescence spectroscopy. Free amino acids are more bioavailable than protein amino acids and, as a consequence, they are usually less concentrated in natural waters. However, free amino acids show higher fluorescence quantum yields than protein amino acids, because lesser 
energy is lost by internal conversion in smaller molecules. As a consequence, free amino acids account for a significant fraction of the protein fluorescence signals. ${ }^{\mathbf{3 8}}$

(b) Humic and fulvic acids (humic substances). They mostly derive from microbial conversion of plant spoils (although other formation pathways are also operational), have still incompletely known chemical structure, and produce distinct fluorescence signals as two broad peaks in the EEM spectrum. These EEM peaks are usually classified on the basis of their excitation (Ex) and emission (Em) wavelengths, and they are termed peak A $(E x / E m=240-260 / 400-500 \mathrm{~nm})$ and peak $\mathrm{C}$ $(E x / E m=300-400 / 400-500 \mathrm{~nm}) .{ }^{\mathbf{1 4}}$ Humic substances occurring in freshwater have fluorescence emission above $400 \mathrm{~nm}^{\mathbf{3 6}}$ and, in some cases, they can be differentiated on the basis of the respective Ex/Em values: indeed, humic acids are usually characterised by longer Ex and Em compared to fulvic acids. ${ }^{39}$ In contrast, in some marine and estuarine samples a humic-like component has been identified that emits around or below $400 \mathrm{~nm}$. This is usually indicated as peak $\mathrm{M}$ (marine humic acids). ${ }^{\mathbf{3 6 , 3 9}}$

(c) Microbial pigments. Photosynthetic pigments and their derivatives, including chlorophylls and pheophytins show Ex $=350-450 \mathrm{~nm}$ and $\mathrm{Em}=650-700 \mathrm{~nm} \cdot{ }^{40}$ Moreover, microorganisms living in UVB-rich environments produce additional pigments that absorb short-wavelength sunlight to protect DNA from radiation-induced damage. Among such pigments, some mycosporin-like amino acids have been reported to fluoresce at $\mathrm{Ex} \sim 330 \mathrm{~nm} / \mathrm{Em} \sim 400 \mathrm{~nm}^{\mathbf{4 1}}$

(d) Fluorescent whitening agents (FWAs). They are man-made compounds that are added to textiles to mask the yellowing of fibres, by emitting fluorescence radiation in the blue region. These compounds can reach surface waters as a consequence of textile washing and of incomplete elimination during wastewater treatment. ${ }^{17}$ Although their concentration in natural waters is usually very low, efficient fluorescence emission ensures that FWAs are sometimes detected in EEM spectra. FWAs usually show a peak that closely overlaps with peak A of humic substances (Ex/Em $=250-255 / 420-430 \mathrm{~nm})$ and may be covered by the latter, plus a more distinct peak $\mathrm{W}(\mathrm{Ex} / \mathrm{Em}=$ $325-335 / 415-425 \mathrm{~nm}){ }^{\mathbf{1 7 , 4 2}}$

Note that the EEM spectra (like that reported in Figure 2) usually show linear signals that are also found in ultra-pure water, and that do not provide information on the nature of fluorescent organic matter: they are the Rayleigh scattering $(\mathrm{Ex}=\mathrm{Em})$ and its second harmonic $(\mathrm{Ex}=1 / 2 \mathrm{Em})$, as well as the Raman signal of water $(\mathrm{Ex}<\mathrm{Em})$ and its second harmonic. Such signals may need to be deleted if further data processing is required. ${ }^{17}$

The fluorescence signals that can be identified in EEM spectra can provide some insight into the type and origin of organic matter occurring in a given sample. ${ }^{\mathbf{4 3}}$ Proteins and free amino acids can be both consumed and produced by aquatic microorganisms, and are released into the extracellular 
environment with the lysis of dead cells. The relevant EEM signals are connected to microbial metabolic activity, ${ }^{\mathbf{4 4}}$ and they are usually a signature of autochthonous or aquagenic organic matter. A similar issue holds for plankton pigments, although these are detected less frequently than proteins or amino acids.

Humic and fulvic acids (HA and FA, respectively) can be aquagenic, ${ }^{\mathbf{4 4 5}}$ but more often they are indicators of allochthonous or soil organic matter. ${ }^{46-48}$ Because different processes may be operational that either generate HA and FA within the aquatic environment, or transport them from land to water, the HA/FA signals should be treated with care as far as the origin of the relevant fluorophores is concerned. Usually, additional information is required from other sources, concerning the type of aquatic environment under study.

Finally, whitening agents are man-made compounds and can be used as wastewater tracers in EEM spectra. ${ }^{17,42}$ Although other compounds can work better as wastewater tracers (e.g., caffeine and especially carbamazepine), they require much more sophisticated analytical techniques based on liquid chromatography-mass spectrometry. ${ }^{\mathbf{4 9 , 5 0}}$ Therefore, inexpensive EEM spectra are sometimes used at a screening level. As far as wastewater is concerned, it is interesting to point out that EEM spectra can also be used as a simple proxy to monitor the quality of wastewater during treatment. ${ }^{\mathbf{5 1}}$ Moreover, because the tyrosine-like and tryptophan-like fluorophores have comparable reactivity as some organic contaminants, fluorescence spectroscopy can be used to obtain surrogate information concerning the transformation (and particularly the photochemical transformation) of trace organic contaminants in wastewater. ${ }^{\mathbf{5 2}}$ However, wastewater treatment is outside of the scope of this paper. In addition to the qualitative insight provided by a mere look at the EEM spectra, additional information can be obtained by EEM data treatment with a mathematical tool named PARAFAC. ${ }^{\mathbf{5 3}}$ This technique has the ability to single out the separate fluorescent components occurring in a series of related spectra, and it may for instance provide key information related to a single FDOM source. PARAFAC has also been used to disentangle relatively weak fluorescence signals from the background provided by humic substances, thereby allowing for the detection of additional compounds. ${ }^{17}$ Despite its usefulness, sometimes the information provided by PARAFAC may be misleading and great care should be taken in data interpretation. Additional information on this technique cannot be provided here, but extensive accounts can be found in the literature. ${ }^{\mathbf{5 3 - 5 6}}$ 


\section{Available tools for the characterisation of natural organic matter}

As said above, fluorescence spectroscopy and especially EEM spectra are some of the most widely used techniques to characterise organic matter in natural water samples, based on the identification of FDOM components. These methods are complementary to the measurement of absorption spectra and of the dissolved organic carbon (DOC), and all together they can provide insight into, for instance, the overall nature of organic matter, its approximate molecular weight and degree of aromaticity. ${ }^{\mathbf{5 7 - 5 9}}$ Therefore, organic matter in natural waters is often characterised by a combination of DOC analysis, absorption spectra and EEM spectra, which can all be carried out on untreated (at most, filtered) water samples. ${ }^{60,61}$

Alternative techniques are also available to characterise organic matter, but they have been used less frequently because they need costly instrumentation and, sometimes, complex procedures of sample pre-treatment. For instance, much of what we currently know about the functional groups in natural organic matter, and especially in humic substances (including their degree of aromaticity) derives from the application of nuclear magnetic resonance (NMR) and Fourier transform infra-red (FT-IR) spectroscopy to organic matter extracts. ${ }^{\mathbf{6 2}-64}$ Unfortunately, these techniques are not sensitive enough to be applied to raw water, thus the organic matter water contains has to undergo concentration procedures to become detectable (however, some advances might enable direct ${ }^{1} \mathrm{H}$ NMR analysis of dissolved organic matter in water samples ${ }^{65}$ ). The other issue is the very high complexity of functional groups that results from these studies. On the one side, this provides invaluable information as to what, for instance, humic substances actually are. ${ }^{61}$ At the same time, however, complex information may be difficult to be treated, and might not always provide the most useful tool to distinguish between different samples.

Recently, Fourier transform ion cyclotron resonance mass spectrometry (FT-ICR-MS) has been used for the characterisation of organic matter. ${ }^{\mathbf{4 3 , 6 6 , 6 7}}$ In this case, very high instrumentation cost is partially offset by sufficiently high sensitivity that allows for direct sample infusion. FT-ICR-MS gives molecular-level information, providing insight into the actual compounds that make up natural organic matter. In this context, a challenge might be that of properly treating the very high amount of information that is obtained from these measurements (in the order of thousands of molecular formulas), to provide intuitive insight into the features of each sample. Mass spectrometric data can be summarised in the form of, e.g., Van Krevelen diagrams (which plot the $\mathrm{H} / \mathrm{C}$ vs. O/C ratio of every molecular formula), ${ }^{\mathbf{6 8}}$ to allow for sample fingerprinting. These diagrams highly simplify the original mass-spectrometric information, but they are still made up of thousands of dots and are more difficult to read compared to EEM spectra. However, they provide different 
and complementary pieces of information compared to fluorescence spectroscopy. More recently, an alternative approach has been developed that is based on high-performance liquid chromatography elution of the organic matter components, coupled online with Orbitrap mass spectrometry. This technique is able to provide additional information on compound polarity ${ }^{68}$ and, at lower instrumentation costs compared to FT-ICR-MS, produces diagrams that can be interpreted more easily.

Despite some unavoidable limitations, it is very likely that fluorescence spectroscopy will still remain in the future one of the most important tools for the characterisation of natural organic matter. By adding information obtained from complementary techniques, it will be possible to get additional and more precise knowledge concerning the origin and cycling of organic matter in surface waters.

\section{Known FDOM fluorophores}

Many structures of natural or anthropogenic fluorophores are rather well known. As mentioned before, tyrosine and tryptophan (as well as phenylalanine to a lesser extent) are the protein fluorophores. ${ }^{14,38}$ Other amino acids (mycosporin-like amino acids, MLAAs, such as porphyra-334 and palythine) occur as plankton pigments and play a role in protection against sunlight $\mathrm{UVB},{ }^{\mathbf{4 1}}$ while pheophytin (Pheo) is a degradation intermediate of chlorophyll (i.e., a chlorophyll molecule that lost the $\mathrm{Mg}^{2+}$ ion). ${ }^{40}$ Fluorescent whitening agents (FWAs), aka optical brighteners (often, stilbene derivatives) are added to textiles because their blue fluorescence emission covers the yellowing of fibres. ${ }^{\mathbf{1 7 4 2}}$ The chemical structures of the mentioned compounds are reported in Figure 3.

\section{On the possible nature of fluorophores in humic substances}

Fluorophores occurring in proteins, plankton pigments and fluorescent whitening agents are quite well known. On the other hand, the reasons behind the fluorescence emission of humic substances (particularly, humic and fulvic acids) are much less understood. The issue of humic fluorophores might recall that of CDOM chromophores, for which there has been a long-term debate concerning their nature. In the case of chromophores, the main issue is that of explaining the nature of CDOM absorption that appears as a quasi-featureless exponential decay of absorbance with increasing wavelength, which contrasts with the absorption bands that are typical of organic molecules. ${ }^{7}$ 
<smiles>NC(Cc1ccc(O)cc1)C(=O)O</smiles>

Tyrosine<smiles>Nc1ccc(/C=C/c2ccc(N)cc2S(=O)(=O)O)c(S(=O)(=O)O)c1</smiles>

4,4'-Diamino-2,2'stilbenedisulfonic acid (FWA)

Tryptophan

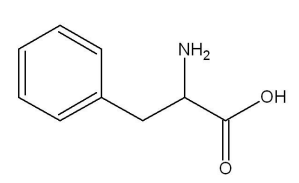

Phenylalanine

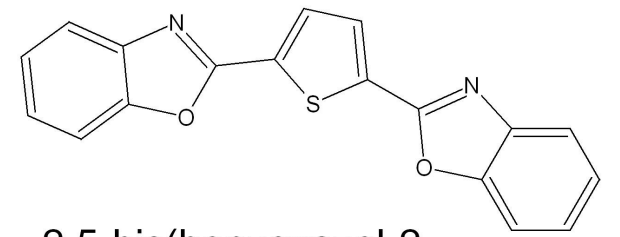

2,5-bis(benzoxazol-2yl)thiophene (FWA)

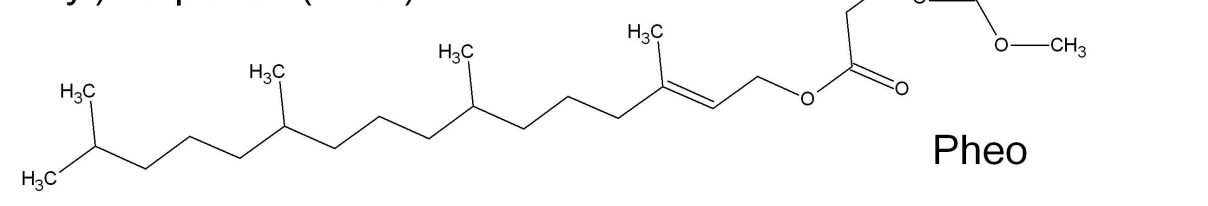

Porphyra-334

(MLAA)

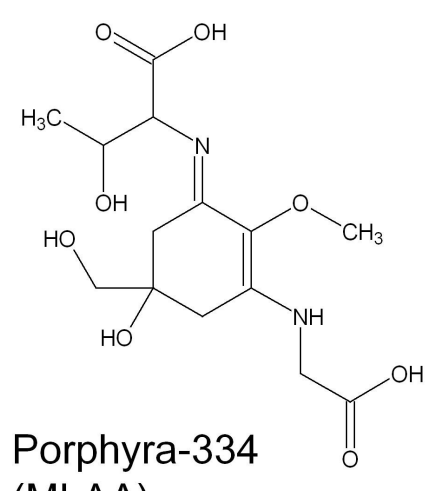

$$
\text { (MLAA) }
$$

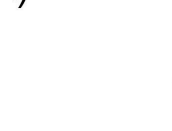<smiles>C=Cc1ccccc1/C=C1\N=CC(CC)=C1C</smiles><smiles>COC1=C(NCC(=O)O)CC(O)(CO)CC1=N</smiles>
(MLAA)

Figure 3. Structures of some compounds discussed in the text as known FDOM fluorophores. MLAA = mycosporin-like amino acid; FWA = fluorescence whitening agent; Pheo = pheophytin.

Two different explanations have been advanced, with no clear consensus reached so far: (i) The peculiar absorption spectra of CDOM derive from molecular interactions, which involve electron donors and acceptors in their excited states (charge-transfer interactions). ${ }^{\mathbf{7 , 8 , 1 1}}$ This theory may have some analogies with the equally controversial supramolecular view, which sees humic substances as made up of small molecules that interact with one another by non-covalent bonds, ${ }^{69}$ as opposed to the macromolecular view ${ }^{\mathbf{7 0}}$ (note, however, that charge-transfer interactions might also occur within different moieties of a large macromolecule). In both cases, the exact nature of the interactions involved (if any) is still incompletely known. (ii) The quasi-exponential CDOM spectrum is actually the sum of a myriad of molecular bands of the different chromophores, each having a neargaussian shape that gets lost among the others. ${ }^{9}$ So far, no conclusive evidence is available in favour of either view. 
The explanation of CDOM absorption, whenever it comes, will not necessarily affect the problem of the fluoresce emission by humic substances. Indeed, although the fluorophores absorb radiation, they have not necessarily to be identical to the chromophores. In analogy with the case of proteins, where the main fluorophores are tyrosine and tryptophan, ${ }^{71}$ it might well be that radiation absorption by humic substances is accounted for by many different compounds, of which only a small minority is fluorescent. A way to look for potential HA and FA fluorophores is to find out compounds that show fluorescence emission in the $\mathrm{A}$ and/or $\mathrm{C}$ regions that are typical of humic substances, and to see whether these compounds are reasonable components of HA and/or FA. In this context, it is interesting to mention the observation that the irradiation of some compounds showing phenolic or protein-like fluorescence produces intermediates with fluorescence emission in the region of humic substances (note that tyrosine is a phenol, thus the fluorescence of proteins partially overlaps with that of phenolic compounds). ${ }^{\mathbf{7 2}}$

To start with, compounds with humic-like behaviour have been detected upon UVC irradiation of phenol. ${ }^{73}$ Upon absorption of UVC radiation, phenol undergoes photolysis to produce the phenoxyl radical, which is prone to further oxidation or to dimerisation (Figure 4). Indeed, phenol dimers (dihydroxybiphenyls and phenoxyphenols) are key intermediates of phenol direct photolysis. ${ }^{\mathbf{7 4 , 7 5}}$ Phenol dimers can then undergo further photolysis with production of oligomers, and it has been suggested that phenol oligomers should emit fluorescence radiation in the region of humic substances. $^{\mathbf{7 6 , 7 7}}$ Moreover, it is reasonable for humic substances to contain phenolic oligomers as lignin breakdown products. ${ }^{\mathbf{7 8}}$

Formation of phenoxyl radicals can also occur upon photoinduced oxidation of phenols. One such example is observed when phenol is irradiated together with triplet sensitisers (aromatic ketones or quinones), the triplet states of which are useful proxies for ${ }^{3} \mathrm{CDOM} *{ }^{79}$ For instance, formation of compounds with humic-like fluorescence has been observed upon irradiation of phenol with anthraquinone-2-sulphonate as triplet sensitiser, ${ }^{77}$ and this photochemical system is well known to produce phenoxy radicals as well as phenol dimers (and, possibly, oligomers). ${ }^{\mathbf{7 9}}$ Possible processes yielding phenoxy radicals in the presence of phenol and irradiated CDOM are shown in Figure 5. 


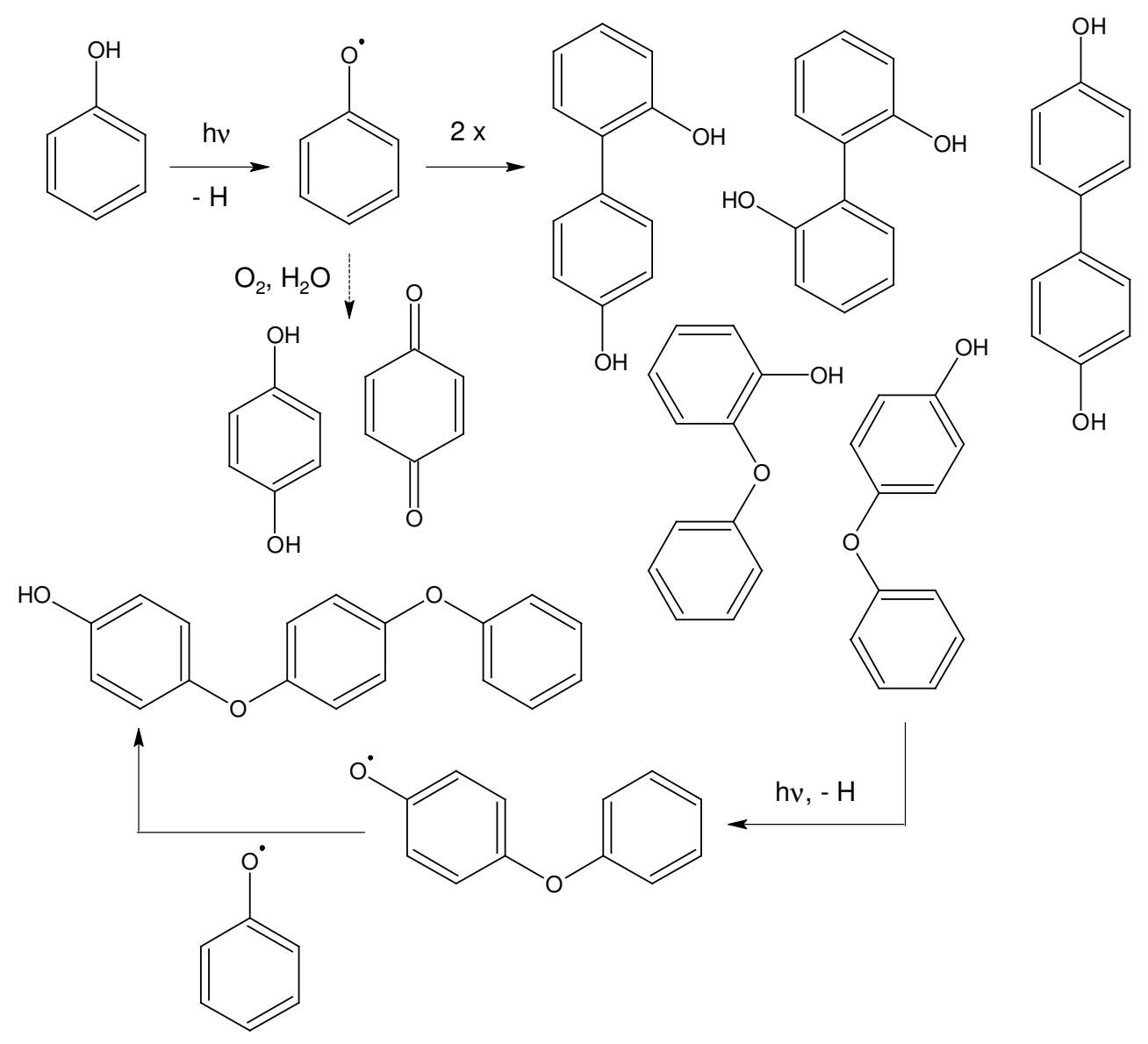

Figure 4. Schematic of the possible processes induced by the UVC photolysis of phenol, and accounting for the formation of oxidised derivatives, phenol dimers and a sample trimeric structure (note that many other phenol trimers can be formed in similar reaction pathways). UVC radiation is not environmentally significant, but phenol is the compound for which this kind of processes is best known. Similar reactions are also involved in the more environmental (UVB) photolysis of tyrosine and other substituted phenols.

More recently, it has been reported that the UVB irradiation of tyrosine and tryptophan produces a gradual shift from protein-like to humic-like fluorescence. ${ }^{72}$ Tyrosine is a phenolic compound and, although its photochemistry is known in much lesser detail compared to that of phenol, a similar explanation (dimerisation/oligomerisation) is expected to hold as well. ${ }^{\mathbf{8 0}}$ In contrast, the direct photolysis of tryptophan causes oxidation/hydroxylation rather than dimerisation, ${ }^{\mathbf{8 1}}$ which should be taken into account when trying to explain the related photoinduced formation of humic-like fluorophores. Indeed, other studies have shown that fluorescence emission in the region of humic substances is also observed in the case of monoaromatic compounds bearing several oxygencontaining substituents. ${ }^{\mathbf{8 2}}$ One such example is ferulic acid, ${ }^{\mathbf{8 3}}$ which is a component of plant cell 
walls and might be found as well in humic substances. It is not unreasonable to think that substances derived from the breakdown of lignin and other vegetal material may act as humic fluorophores. However, additional research is needed to understand if the mentioned fluorophores share other common features with humic substances, in addition to the fluorescence spectra. ${ }^{\mathbf{8 4}}$ Interestingly, the photochemical formation of substances with humic-like fluorescence from tyrosine and tryptophan might open up the possibility of a photoinduced pathway for the generation of humic substances from free amino acids. There are field data that actually report the daytime transformation of substances released from living organisms into aquagenic humic-like compounds, but it is always difficult to distinguish between purely photochemical, purely biological and mixed processes in field studies. ${ }^{\mathbf{8 5}}$ At the same time, however, one should consider that exposure to sunlight also causes photobleaching of CDOM and particularly of humic substances (see next section). ${ }^{\mathbf{8 6 , 8 7}}$

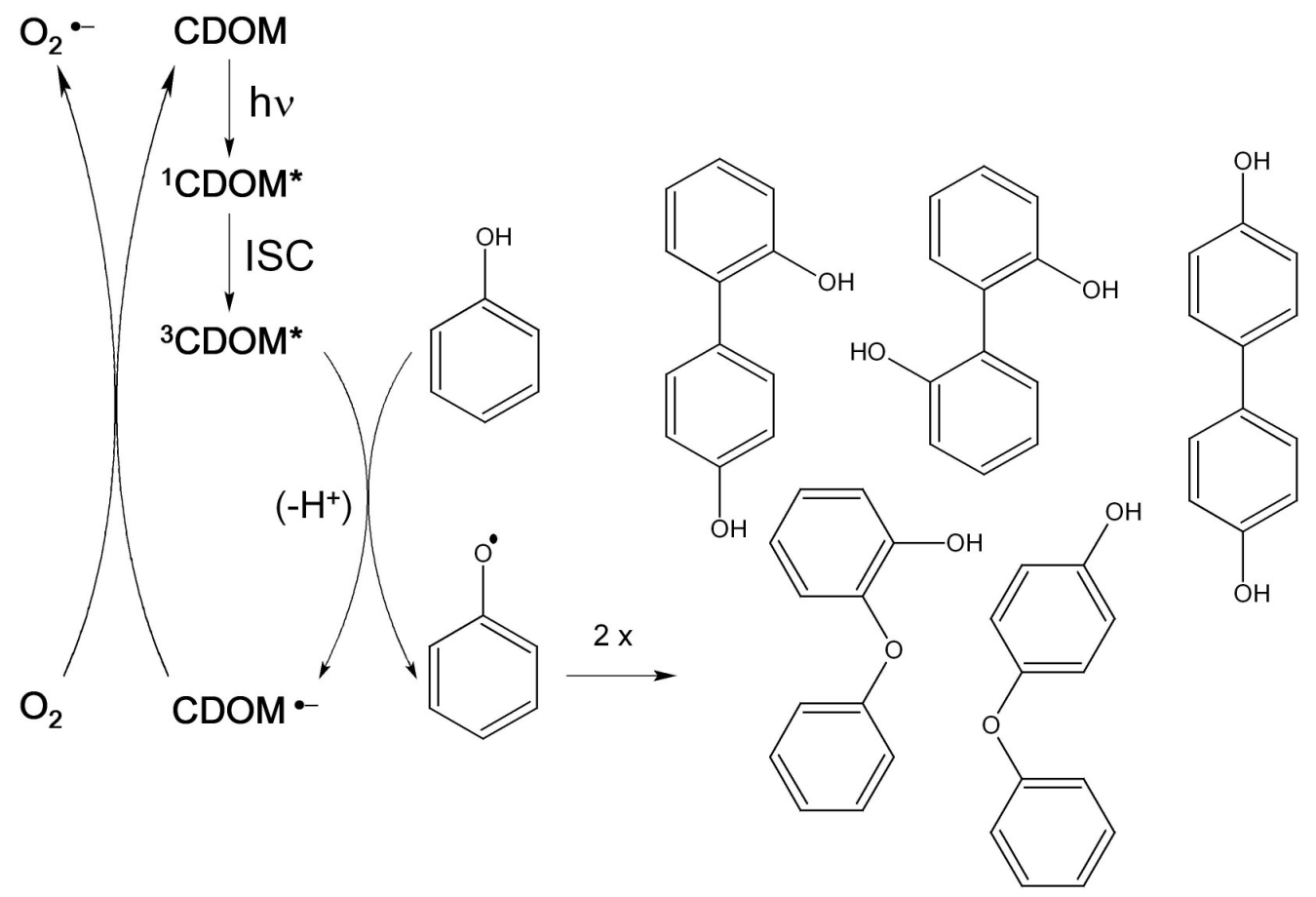

Figure 5. Possible formation of phenoxyl radicals and dimeric species of phenol in the presence of chromophoric dissolved organic matter $(\mathrm{CDOM})$ and phenol under sunlight irradiation. ISC = intersystem crossing. 


\section{Photobleaching vs. photoinduced generation of humic substances}

When humic substances are exposed to sunlight, their absorbance usually decreases as a consequence of radiation absorption (photobleaching). ${ }^{\mathbf{8 8 , 8 9}}$ The rationale is that compounds that undergo phototransformation produce intermediates that, in principle, might absorb sunlight to a higher or lesser extent compared to the parent molecules. Radiation absorption is a necessary condition for phototransformation, although not a sufficient one: indeed, the probability of undergoing transformation upon absorption of a photon (i.e., the direct photolysis quantum yield) ${ }^{\mathbf{9 0}}$ also plays a key role. However, in general, strong radiation absorbers are more likely to undergo photodegradation compared to weak absorbers, and the same applies to their phototransformation intermediates. These, in turn, yield compounds with variable (higher or lower) ability to absorb sunlight. If, on average, photodegradation proceeds fast with strongly absorbing compounds and slows down with weak absorbers, and if sunlight exposure is long enough, the most likely outcome is the eventual production of molecules with low ability to absorb sunlight. Coherently, photobleaching is observed very often in irradiated natural waters. ${ }^{91}$ Moreover, because radiation absorption is an important prerequisite for fluorescence emission, there is potential for sunlight exposure to degrade both the chromophores and important fluorophores in organic matter. ${ }^{\mathbf{8 6}, 87}$

The above considerations suggest that natural waters that have undergone prolonged exposure to sunlight should show relatively low values of the absorbance, together with weak fluorescence signals in the region of humic substances (i.e., the main sunlight-absorbing fluorophores). However, the above framework is complicated by the occurrence of aquagenic humic substances in some natural water samples. ${ }^{\mathbf{8 5 2}}$ As mentioned previously, most humic substances are generated in soil and are then transported to the aquatic compartment. ${ }^{\mathbf{9 2 9 3}}$ Still, a fraction of HA and FA actually originates from aquatic processes. A first possibility is the in-water microbial processing of plant and animal spoils or of dead algae. It is difficult to separate the contributions of microbes alone and of microbes + sunlight in these processes, at least because sunlight might help algal growth and thus provide additional raw materials and metabolic potential for the generation of aquagenic HA and FA. ${ }^{85}$ Another possibility is the action of sunlight on amino acids and phenolic compounds, which is able to transform them into species that have both humic-like absorbance and humic-like fluorescence. $^{72}$

The fluorescence intensity of humic substances in natural water samples would thus depend on the budget between export from soil, generation in the aquatic environment, and photobleaching. In contrast, there is evidence that protein fluorescence would be less affected by photobleaching compared to humic fluorescence. ${ }^{91}$ For instance, selective photobleaching of humic substances 
coupled with algal growth might explain why water samples from clear mountain lakes can show only protein fluorescence in late summer, ${ }^{\mathbf{1 5}}$ while this is not the case for samples taken in early summer soon after ice melt (see Figure 2).

The processes mentioned above (algal growth, organic matter export from soil, photobleaching) have the potential to enhance or decrease the occurrence of fluorophores in natural waters. Interestingly, some of these processes may be impacted by climate change. Although the effects of climate change on natural-water fluorophores are not known in detail, it is still possible to make some tentative inferences in the framework of some peculiar climate-related scenarios, as shown in the next section.

\section{Possible links between fluorophores and climate change}

Climate change has the potential to deeply alter water resources on a worldwide scale, with possibly important increase or decrease in water availability in different areas of the world. ${ }^{\mathbf{9 4}}$ Here two foreseen climate-related scenarios are considered: (i) longer and more stable stratification of lake waters because of warmer summer seasons, ${ }^{\mathbf{9 5}}$ and (ii) evaporative concentration of solutes in sunlit water bodies, especially during drought periods. ${ }^{\mathbf{9 6}}$ These phenomena have potential effects on algal growth and algal blooms, and on the way surface waters are exposed to sunlight.

\section{Fluorophores in stratified lakes}

Lakes that are deep enough can become stratified during the summer season. In this case, sunlight illuminates the surface water layer that becomes warmer and, thus, less dense. The onset of stratification in lake water occurs when the warmer surface layer (epilimnion) floats over the colder and denser deep water (hypolimnion). Both photosynthesis and gas exchange with the atmosphere occur in the epilimnion, but reduced exchange of solutes with the hypolimnion has the consequence that the latter may become oxygen-poor or, sometimes, even anoxic. In the case of shallow lakes, thermal stratification can be broken by the mechanical action of wind (polymittic lakes, which can undergo many cycles of stratification and overturn). ${ }^{97}$

Due to global warming, hotter summers are expected to considerably increase the temperature in the epilimnion so that summer stratification becomes more stable and can last for a longer time, especially in deep lakes. ${ }^{\mathbf{9 5}}$ The occurrence of warm water may be favourable to algal growth, although there are some caveats concerning a possible temperature threshold above which the growth of algae might slow down or even stop, especially in the presence of limiting nutrients. ${ }^{\mathbf{9 8}}$ An additional phenomenon is that an earlier onset of stratification in spring might induce some algal 
species to grow sooner, thereby anticipating the growth of grazers and finally ending up with higher algal concentrations. ${ }^{\mathbf{9 9}}$ Overall, all factors considered, algal blooms should become increasingly common in a warmer world. ${ }^{\mathbf{9 8 , 9 9}}$ In some cases algal blooms may give rise to the production of cyanotoxins, ${ }^{100}$ but in general the growth and death of algae should make aquagenic DOM (and, among this, protein-like FDOM) more common in lake water and, specifically, in the epilimnion.

In a stratified lake, the epilimnion is exposed to sunlight and its depth is lower compared to the average depth of the whole lake. Therefore, compared to a whole overturning lake the epilimnion is better illuminated by sunlight, and the photochemical reactions (including photobleaching of organic matter) are faster as a consequence. ${ }^{\mathbf{1 0 1}}$ Longer lake stratification during summer, when sunlight is also more intense, is thus expected to enhance photobleaching in the epilimnion, and photobleaching is known to affect humic-like substances to a higher extent compared to protein-like substances. $^{91}$

Overall, longer summer stratification might enhance protein fluorophores in the epilimnion due to algal growth, and increase the relative ratio of protein-like to humic-like fluorophores due to selective photobleaching. This is expected to happen, unless in-water humification processes or precipitation and the related runoff from soil restore the concentration of humic substances in the water matrix (vide infra).

Summertime precipitation deserves some mention in this context. In a warmer world one might expect higher water evaporation and, therefore, higher average precipitations worldwide. ${ }^{\mathbf{1 0 2}}$ However, increased precipitation will not be evenly distributed on our planet, and many areas (especially those that are already arid) might actually experience precipitation decrease. ${ }^{\mathbf{1 0 3 , 1 0 4}}$ Furthermore, there will be important changes in the distribution of precipitation over time, even in areas where average values are unaffected. A common prediction of climate models is that rain will be distributed over fewer rainy days, with an increased probability of extreme events. ${ }^{\mathbf{1 0 5}}$ Interestingly, heavy rainfall enhances the transport of soil organic matter into surface waters (see Figure 6). ${ }^{\mathbf{1 0 6}}$ Therefore, intense summer storms might offset to a variable extent the increased photobleaching of humic substances. At the same time, however, heavy rain can mobilise nutrients that enhance algal growth, ${ }^{\mathbf{1 0 7}}$ with the consequence that fluorophores in lake water might have a hardly predictable trend in stormy summers. In contrast, arid summers are more likely to experience enhanced photobleaching of humic substances that should increase the ratio between protein-like and humic-like fluorophores. 


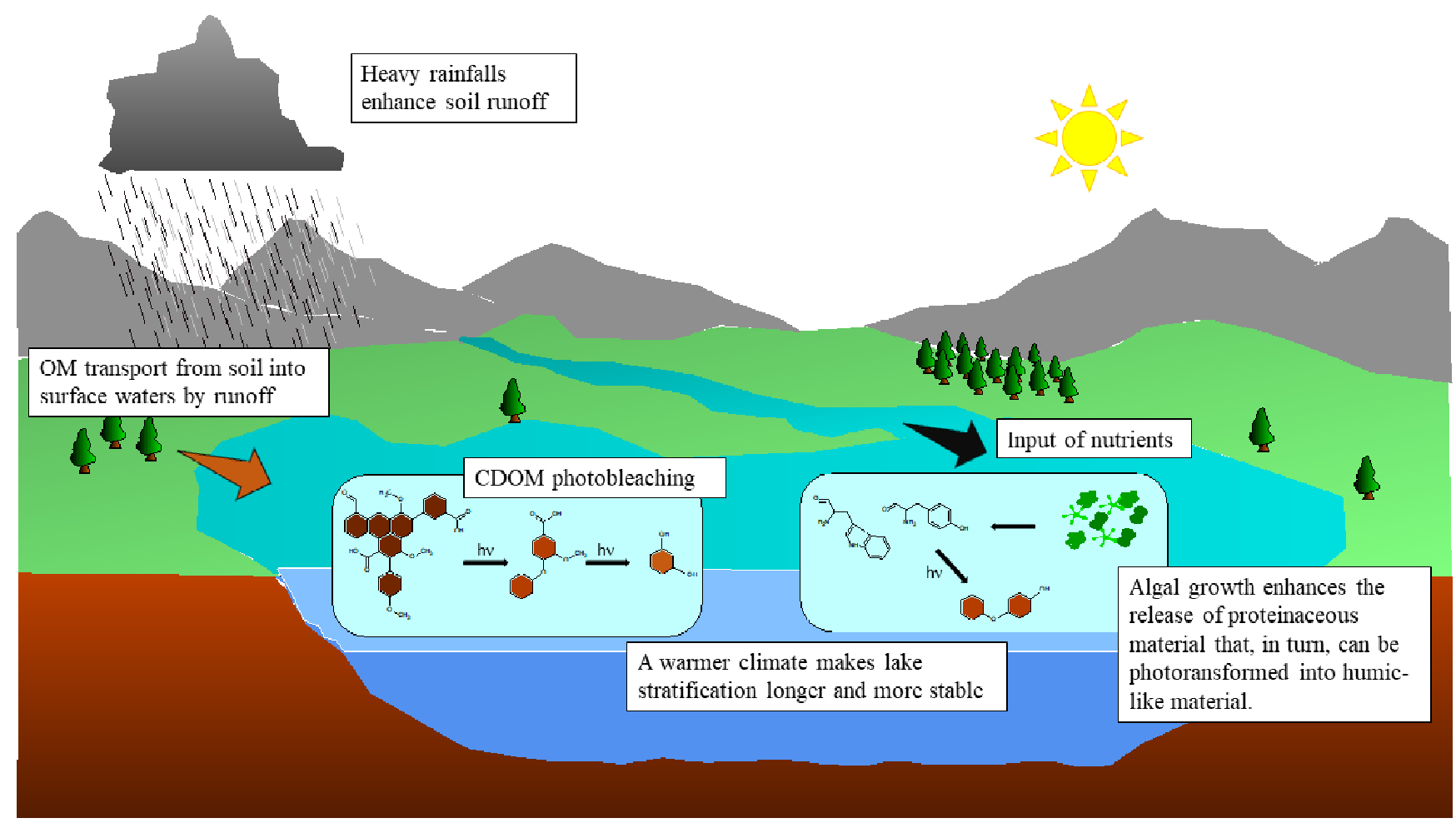

Figure 6. Simplified scheme showing the possible effects of a warmer climate on DOM fluorophores in a stratified lake. 'OM' means 'organic matter'.

\section{Evaporative water concentration}

If no precipitations occur during the summer season, elevated temperatures can induce water evaporation that becomes important in environments with limited water runoff, and that increases the concentration of solutes such as organic matter and ions. ${ }^{\mathbf{1 0 8 , 1 0 9}}$ The same phenomenon can occur during long drought periods, such as for instance in Australia during the so-called "millennium drought". ${ }^{96,110}$ Water evaporation enhances the concentration of salts, including nutrients such as nitrate and phosphate. Moreover, shallower water might facilitate resuspension of sediment and thus mobilise additional nutrients. ${ }^{108}$ The combination of both phenomena triggers algal growth, and has thus the potential to increase the concentration values of aquagenic organic matter (Figure 7).

Shallower water columns are usually better illuminated by sunlight. However, in the case of evaporative concentration the decrease in water depth is more or less fully offset by the increasing concentration of organic matter in general, and of CDOM in particular. ${ }^{111}$ As a result, sunlight penetration in water and the associated photobleaching of humic-like substances might not be modified as water evaporates. Moreover, evaporative concentration necessarily takes place in the absence of precipitation, which excludes soil runoff of pedogenic organic matter. There is thus potential for the contribution of aquagenic fluorophores to overcome that of pedogenic fluorophores 
as the evaporation process goes on. Unfortunately, EEM spectra of water samples were not taken during the 2000s drought in Australia, and the possible consequences of these phenomena on FDOM can only be speculated.

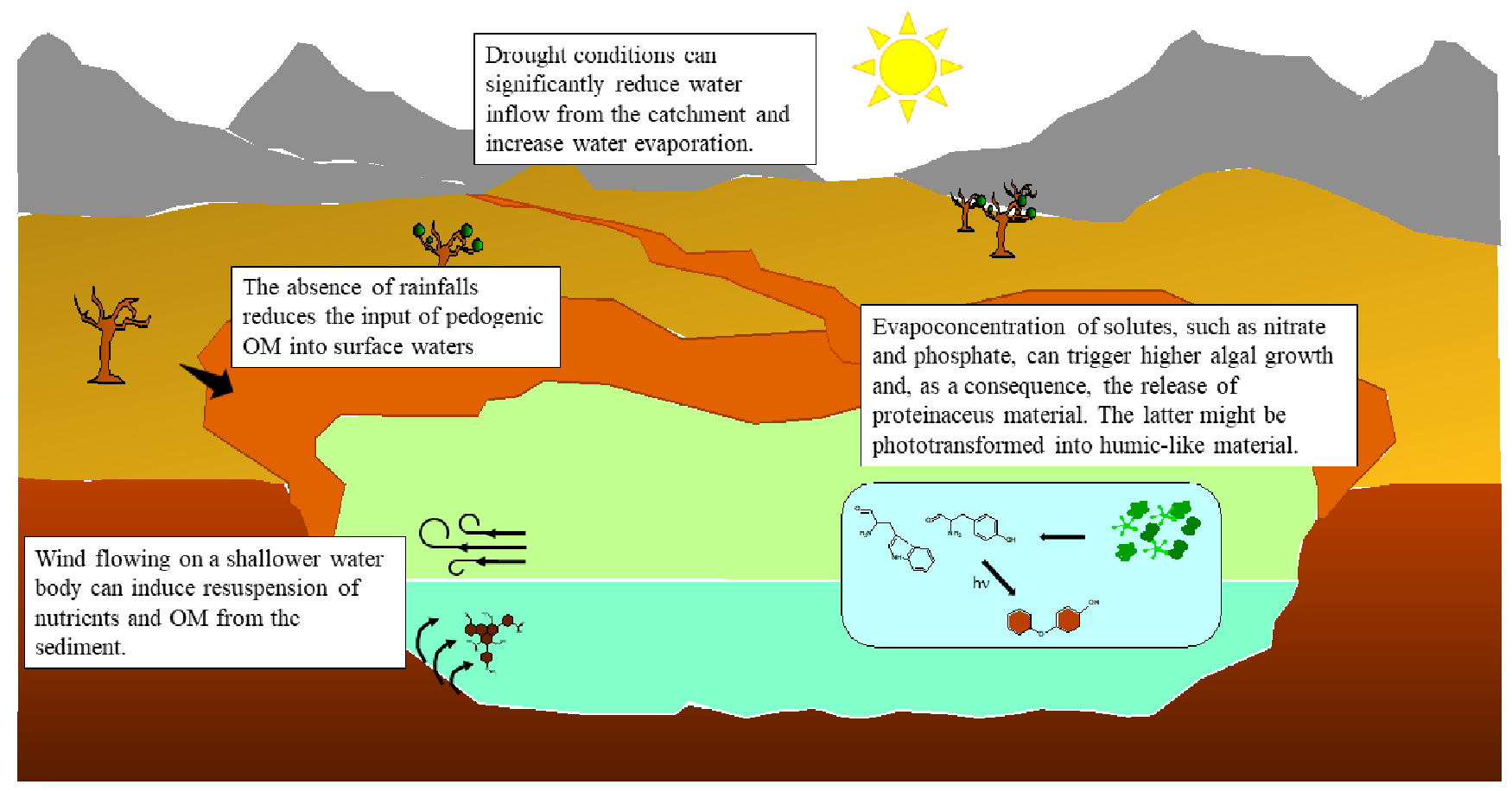

Figure 7. Simplified scheme showing the possible effects of evaporative water concentration due to drought conditions on DOM fluorophores in a shallow lake. 'OM' means 'organic matter'.

\section{Conclusions}

Natural waters contain a range of fluorophores that can be detected by fluorescence spectroscopy, such as proteins and free amino acids, humic substances and, usually to a lesser extent, plankton pigments and fluorescent whitening agents. Fluorescence spectroscopy, and especially the EEM spectra is a very useful tool for the characterisation of natural organic matter: it allows for the identification of different components and, sometimes, also of the origin (aquagenic, pedogenic, anthropogenic) of organic matter. The fluorophores in proteins (tyrosine, tryptophan) are quite well known, while the fluorescence of humic substances still deserves an appropriate explanation. Degraded vegetal material, such as phenol oligomers and organic acids occurring in cell walls might possibly account for at least part of the humic-like fluorescence, but additional investigations are needed in this field. 
The occurrence in natural waters of the main fluorescent compounds depends on several issues. Biological activity is the main driver for the occurrence of protein-like fluorescence, while humiclike fluorescence involves a more complex interplay between transport of pedogenic humic substances from soil to surface waters, in-water generation of aquagenic humic compounds (microbial and/or photochemical), and photobleaching. All these processes might be affected by climate change and, for instance, enhanced algal growth in warmer waters will likely increase the occurrence of aquagenic organic matter. At the same time, export from soil of pedogenic organic matter would be enhanced by intense precipitation events. Finally, the importance of photobleaching in the epilimnion might increase in the presence of longer stratification periods in lakes during hotter summer seasons, with expected higher impact on humic compounds than on proteins. A tentative analysis of some scenarios suggests that the importance of aquagenic organic matter should increase over the pedogenic one, with predictions being more difficult in the case of summer periods characterised by heavy rain events.

Conflict of interest. The authors declare no conflict of interest. 


\section{References}

1. J. E. Thrane, D. O. Hessen and T. Andersen, The absorption of light in lakes: Negative impact of dissolved organic carbon on primary productivity. Ecosystems, 2014, 17, 1040-1052.

2. C. Nima, Ø. Frette, B. Hamre, J. J. Stamnes, Y.-C. Chen, K. Sørensen, M. Norli, D. Lu, Q. Xing, D. Muyimbwa, T. Ssenyonga, K. H. Stamnes and S. R. Erga, CDOM absorption properties of natural water bodies along extreme environmental gradients. Water, 2019, 11, article n. 1988.

3. L. Bracchini, A. M. Dattilo, M. Falcucci, S. A. Loiselle, V. Hull, C. Arena and C. Rossi, Spatial and temporal variations of the inherent and apparent optical properties in a shallow coastal lake, J. Photochem. Photobiol. B: Biol., 2005, 80, 161-177.

4. Mostofa, K.M.G., Yoshioka, T., Mottaleb, A. and D. Vione, Photobiogeochemistry of organic matter: principles and practices in water environments. Springer, Berlin, Heidelberg, 2012.

5. J. R. Helms, A. Stubbins, J. D. Ritchie, E. C. Minor, D. J. Kieber and K. Mopper, Absorption spectral slopes and slope ratios as indicators of molecular weight, source, and photobleaching of chromophoric dissolved organic matter, Limnol. Oceanogr., 2008, 53, 955-969.

6. C. G. Fichot and R. Benner, The spectral slope coefficient of chromophoric dissolved organic matter (S275-295) as a tracer of terrigenous dissolved organic carbon in river-influenced ocean margins, Limnol. Oceanogr., 2012, 57, 1453-1466.

7. R. Del Vecchio, N. V. Blough, On the origin of the optical properties of humic substances, Environ. Sci. Technol., 2004, 38, 3885-3891.

8. C. M. Sharpless and N. V. Blough, The importance of charge-transfer interactions in determining chromophoric dissolved organic matter (CDOM) optical and photochemical properties, Environ. Sci.: Processes Impacts, 2014, 16, 654-671.

9. G. McKay, J. A. Korak, P. R. Erickson, D. E. Latch, K. McNeill and F. L. Rosario-Ortiz, The case against charge transfer interactions in dissolved organic matter photophysics, Environ. Sci. Technol., 2018, 52, 406-414.

10. E. A. Vialykh, G. McKay and F. L. Rosario-Ortiz, Computational assessment of the threedimensional configuration of dissolved organic matter chromophores and influence on absorption spectra, Environ. Sci. Technol., 2020, 54, 15904-15913.

11. Y. Chen, J. Liu, X. Zhang and N. V. Blough, Time-resolved fluorescence spectra of untreated and sodium borohydride-reduced chromophoric dissolved organic matter, Environ. Sci. Technol., 2020, 54, 12109-12118. 
12. S. A. Loiselle, L. Bracchini, A. M. Dattilo, M. Ricci, A. Tognazzi, A. Cózar and C. Rossi, The optical characterization of chromophoric dissolved organic matter using wavelength distribution of absorption spectral slopes, Limnol. Oceanogr., 2009, 54, 590-597.

13. L. Galgani, A. Tognazzi, C. Rossi, M. Ricci, J. A. Galvez, A. M. Dattilo, A. Cozar, L. Bracchini and S. A. Loiselle, Assessing the optical changes in dissolved organic matter in humic lakes by spectral slope distributions, J. Photochem. Photobiol. B: Biol., 2011, 102, 132139.

14. P. G. Coble, Characterization of marine and terrestrial DOM in seawater using excitationemission spectroscopy, Mar. Chem., 1996, 51, 325-346.

15. E. De Laurentiis, M. Minella, V. Maurino, C. Minero, M. Brigante, G. Mailhot and D. Vione, Photochemical production of organic matter triplet states in water samples from mountain lakes, located below or above the tree line, Chemosphere, 2012, 88, 1208-1213.

16. R. Losantos, D. Sampedro and M. S. Churio, Photochemistry and photophysics of mycosporine-like amino acids and gadusols, nature's ultraviolet screens, Pure Appl. Chem., 2015, 87, 979-996.

17. N. M. Niloy, M. M. Haque and S. M. Tareq, Fluorescent whitening agents in commercial detergent: A potential marker of emerging anthropogenic pollution in freshwater of Bangladesh, Environ. Nanotechnol. Monitor. Manag., 2021, 15, article n. 100419.

18. L. Mielnik and P. Kowalczuk, Optical characteristic of humic acids from lake sediments by excitation-emission matrix fluorescence with PARAFAC model, J. Soils Sediments, 2018, 18, 2851-2862.

19. X. Xu, J. Kang, J. Shen, S. Zhao, B. Wang, X. Zhang and Z. Chen, EEM-PARAFAC characterization of dissolved organic matter and its relationship with disinfection by-products formation potential in drinking water sources of northeastern China, Sci. Total Environ., 2021, 774, 145297.

20. M. Kasha, Characterization of electronic transitions in complex molecules, Discuss Faraday Soc., 1950, 9, 14-19.

21. N. J. Turro, V. Ramamurthy, W. Cherry and W. Farneth, The effect of wavelength on organic photoreactions in solution. Reactions from upper excited states, Chem. Rev., 1978, 78, 125145.

22. Y. Yamashita, R. Jaffé, N. Maie and E. Tanoue, Assessing the dynamics of dissolved organic matter (DOM) in coastal environments by excitation emission matrix fluorescence and parallel factor analysis (EEM-PARAFAC), Limnol. Oceanogr., 2008, 53, 1900-1908. 
23. D. P. Häder, C. E. Williamson, S.-A. Wängberg, M. Rautio, K. C. Rose, K. Gao, E. W. Helbling, R. P. Sinha and R. Worrest, Effects of UV radiation on aquatic ecosystems and interactions with other environmental factors, Photochem. Photobiol. Sci., 2015, 14, 108-126.

24. B. Tartarotti, F. Trattner, D. Remias, N. Saul, C. E. W. Steinberg and R. Sommaruga, Distribution and UV protection strategies of zooplankton in clear and glacier-fed alpine lakes, Sci. Rep., 2017, 7, article n. 4487.

25. C. E. Williamson, E. P. Overholt, R. M. Pilla, T. H. Leach, J. A. Brentrup, L. B. Knoll, E. M. Mette and R. E. Moeller, Ecological consequences of long-term browning in lakes, Sci. Rep., 2015, 5, article n. 18666.

26. G. A. Weyhenmeyer, R. A. Müller, M. Norman and L. J. Tranvik, Sensitivity of freshwaters to browning in response to future climate change, Clim. Change, 2016, 134, 225-239.

27. S. B. Partanen, P. R. Erickson, D. E. Latch, K. J. Moor and K. McNeill, Dissolved organic matter singlet oxygen quantum yields: Evaluation using time-resolved singlet oxygen phosphorescence, Environ. Sci. Technol., 2020, 54, 3316-3324.

28. S. C. Remke, U. von Gunten and S. Canonica, Enhanced transformation of aquatic organic compounds by long-lived photooxidants (LLPO) produced from dissolved organic matter, Water Res., 2021, 190, article n. 116707.

29. L. Carena, S. Comis and D. Vione, Geographical and temporal assessment of the photochemical decontamination potential of river waters from agrochemicals: A first application to the Piedmont region (NW Italy), Chemosphere, 2021, 263, article n. 127921.

30. S. Yan and W. Song, Photo-transformation of pharmaceutically active compounds in the aqueous environment: a review, Environ. Sci. Process Impacts, 2014, 16, 697-720.

31. R. Sommaruga, The role of solar UV radiation in the ecology of alpine lakes, J. Photochem. Photobiol. B: Biol., 2001, 62, 35-42.

32. J. M. Fischer, M. H. Olson, N. Theodore, C. E. Williamson, K. C. Rose, J. Hwang, Diel vertical migration of copepods in mountain lakes: The changing role of ultraviolet radiation across a transparency gradient, Limnol. Oceanogr., 2015, 60, 252-262.

33. K. Komatsu, A. Imai and N. Kawasaki, Comparison between humic-like peaks in excitationemission matrix spectra and resin-fractionated humic substances in aquatic environments, Limnology, 2019, 20, 109-120.

34. Y. Luo, Y. Zhang, M. Lang, X. Guo, T. Xia, T. Wang, H. Jia and L. Zhu, Identification of sources, characteristics and photochemical transformations of dissolved organic matter with EEM-PARAFAC in the Wei River of China, Front. Environ. Sci. Eng., 2021, 15, article n. 96. 
35. A. S. C. Monteiro, M. A. A. Santana, R. S. A. Ch'ielle, C. A. B. Garcia and J. P. H. Alves, Characterization of aquatic organic matter in a natural environment in Northeastern Brazil, Quim. Nova, 2021, 43, 1431-1438.

36. J. Bridgeman, M. Bieroza and A. Baker, The application of fluorescence spectroscopy to organic matter characterisation in drinking water treatment, Rev. Environ. Sci. Biotechnol., 2011, 10, article n. 277.

37. N. J. Hudson, A. Baker and D. Reynolds, Fluorescence analysis of dissolved organic matter in natural, waste and polluted waters - a review, River Res. Appl., 2007, 23, 631-649.

38. O. E. Trubetskaya, C. Richard and O. A. Trubetskoj, High amounts of free aromatic amino acids in the protein-like fluorescence of water-dissolved organic matter, Environ. Chem. Lett., 2016, 14, 495-500.

39. M. M. Sierra, M. Giovanela, E. Parlanti and E. J. Soriano-Sierra, Fluorescence fingerprint of fulvic and humic acids from varied origins as viewed by single-scan and excitation/emission matrix techniques, Chemosphere, 2005, 58, 715-733.

40. R. Bhattacharya and C. L. Osburn, Multivariate analyses of phytoplankton pigment fluorescence from a freshwater river network, Environ. Sci. Technol., 2017, 51, 6683-6690.

41. N. Wada, T. Sakamoto and S. Matsugo, Mycosporine-like amino acids and their derivatives as natural antioxidants, Antioxidants (Basel), 2015, 4, 603-646.

42. K. M. G. Mostofa, F. C. Wu, C. Q. Liu, W. L. Fang, J. Yuan, W. L. Ying, L. Wen and M. Yi, Characterization of Nanming River (Southwestern China) impacted by sewerage pollution using excitation-emission matrix and PARAFAC, Limnology, 2010, 11, 217-231.

43. A. Stubbins, J.-F. Lapierre, M. Berggren, Y. T. Prairie, T. Dittmar and P. A. del Giorgio, What's in an EEM? Molecular signatures associated with dissolved organic fluorescence in Boreal Canada, Environ. Sci. Technol., 2014, 48, 10598-10606.

44. B. G. Fox, R. M. S. Thorn, A. M. Anesio, T. Cox, J. W. Attridge and D. M. Reynolds, Microbial processing and production of aquatic fluorescent organic matter in a model freshwater system, Water, 2019, 11, article n. 10.

45. F. Guillemette and P. A. del Giorgio, Simultaneous consumption and production of fluorescent dissolved organic matter by lake bacterioplankton. Environ. Microbiol., 2012, 14, 1432-1443.

46. P. Westerhoff and D. Anning, Concentrations and characteristics of organic carbon in surface water in Arizona: influence of urbanization. J. Hydrol., 2000, 236, 202-222. 
47. D. M. McKnight, E. W. Boyer, P. K. Westerhoff, P. T. Doran, T. Kulbe and D. T. Andersen, Spectrofluorometric characterization of dissolved organic matter for indication of precursor organic material and aromaticity, Limnol. Oceanogr., 2001, 46, 38-48.

48. J. L. Oliveira, M. Boroski, J. C. R. Azevedo and J. Nozaki, Spectroscopic investigation of humic substances in a tropical lake during a complete hydrological cycle, Acta Hydrochim. Hydrobiol., 2006, 34, 608-617.

49. G. Gasser, M. Rona, A. Voloshenko, R. Shelkov, N. Tal, I. Pankratov, S. Elhanany and O. Lev, Quantitative evaluation of tracers for quantification of wastewater contamination of potable water sources, Environ. Sci. Technol., 2010, 44, 3919-3925.

50. N. Z. Dvory, Y. Livshitz, M. Kuznetsov, E. Adar, G. Gasser, I. Pankratov, O. Lev and A. Yakirevich, Caffeine vs. carbamazepine as indicators of wastewater pollution in a karst aquifer, Hydrol. Earth Syst. Sci., 2018, 22, 6371-6381.

51. E. M. Carstea, J. Bridgeman, A. Baker and D. M. Reynolds, Fluorescence spectroscopy for wastewater monitoring: A review, Water Res., 2016, 95, 205-219.

52. Yan, S., Yao, B., Lian, L., Lu, X., Snyder, S. A., Li, R. and W. Song, Development of fluorescence surrogates to predict the photochemical transformation of pharmaceuticals in wastewater effluents. Environ. Sci. Technol. 2017, 51, 2738-2747.

53. K. R. Murphy, C. A. Stedmon, D. Graeber and R. Bro, Fluorescence spectroscopy and multiway techniques. PARAFAC, Anal. Methods, 2013, 5, 6557-6566.

54. L. Yang, J. Hur and W. Zhuang, Occurrence and behaviors of fluorescence EEM-PARAFAC components in drinking water and wastewater treatment systems and their applications: a review, Environ. Sci. Pollut. Res., 2015, 22, 6500-6510.

55. C. M. Andersen and R. Bro, Practical aspects of PARAFAC modeling of fluorescence excitation-emission data, J. Chemometrics, 2003, 17, 200-215.

56. X. Luciani, S. Mounier, R. Redon and A. Bois, A simple correction method of inner filter effects affecting FEEM and its application to the PARAFAC decomposition, Chemometrics Intell. Labor. Syst. 2009, 96, 227-238.

57. J. L. Weishaar, G. R. Aiken, B. A. Bergamaschi, M. S. Fram, R. Fujii, and K. Mopper, Evaluation of specific ultraviolet absorbance as an indicator of the chemical composition and reactivity of dissolved organic carbon, Environ. Sci. Technol., 2003, 37, 4702-4708.

58. : P. Li and J. Hur, Utilization of UV-Vis spectroscopy and related data analyses for dissolved organic matter (DOM) studies: A review, Crit. Rev. Environ. Sci. Technol., 2017, 47, 131154. 
59. J. Peuravuori and K. Pihlaja, Molecular size distribution and spectroscopic properties of aquatic humic substances, Anal. Chim. Acta, 1997, 337, 133-149.

60. A. M. Hansen, T. E. C. Kraus, B. A. Pellerin, J. A. Fleck, B. D. Downing, B. A. Bergamaschi, Optical properties of dissolved organic matter (DOM): Effects of biological and photolytic degradation, Limnol. Oceanogr., 2016, 61, 1015-1032.

61. W. Machado, J. C. Franchini, M. F. Guimarães and J. T. Filho, Spectroscopic characterization of humic and fulvic acids in soil aggregates, Brazil, Helyon, 2020, 6, article n. e04078.

62. K. Mopper, A. Stubbins, J. D. Ritchie, H. M. Bialk and P. G. Hatcher, Advanced instrumental approaches for characterization of marine dissolved organic matter: Extraction techniques, mass spectrometry, and nuclear magnetic resonance spectroscopy, Chem. Rev., 2007, 107, 419-442.

63. J. Mao, X. Cao, D. C. Olk, W. Chu and K. Schmidt-Rohr, Advanced solid-state NMR spectroscopy of natural organic matter, Progr. Nucl. Magn. Res. Spectr., 2017, 100, 17-51.

64. E. C. Minor, M. M. Swenson, B. M. Mattson and A. R. Oyler, Structural characterization of dissolved organic matter: a review of current techniques for isolation and analysis, Environ. Sci.: Processes Impacts, 2014, 16, 2064-2079.

65. B. Lam and A. J. Simpson, Direct ${ }^{1} \mathrm{H}-\mathrm{NMR}$ spectroscopy of dissolved organic matter in natural waters, Analyst, 2008, 133, 263-269.

66. M. M. Tfaily, R. Hamdan, J. E. Corbett, J. P. Chanton, P. H. Glaser and W. T. Cooper, Investigating dissolved organic matter decomposition in northern peatlands using complimentary analytical techniques, Geochim. Cosmochim. Acta, 2013, 112, 116-129.

67. B. P. Koch, M. Witt, R. Engbrodt, T. Dittmar and G. Kattner, Molecular formulae of marine and terrigenous dissolved organic matter detected by electrospray ionization Fourier transform ion cyclotron resonance mass spectrometry, Geochim. Cosmochim. Acta, 2005, 69, 3299-3308.

68. C. Patriarca, J. Bergquist, P. J. R. Sjoberg, L. Tranvik and J. A. Hawkes, Online HPLC-ESIHRMS method for the analysis and comparison of different dissolved organic matter samples. Environ. Sci. Technol., 2018, 52, 2091-2099.

69. A. Piccolo, The supramolecular structure of humic substances, Soil Science, 2001, 166, 810832.

70. S. Capasso, S. Chianese, D. Musmarra and P. Iovino, Macromolecular structure of a commercial humic acid sample, Environments, 2020, 7, article n. 32.

71. Y. Yamashita and E. Tanoue, Chemical characterization of protein-like fluorophores in DOM in relation to aromatic amino acids, Mar. Chem., 2003, 82, 255-271. 
72. A. Bianco, M. Minella, E. De Laurentiis, V. Maurino, C. Minero and D. Vione, Photochemical generation of photoactive compounds with fulvic-like and humic-like fluorescence in aqueous solution, Chemosphere, 2014, 111, 529-536.

73. J. P. Aguer and C. Richard, Photochemical behaviour of humic acid synthesized from phenol, J. Photochem. Photobiol. A: Chem., 1994, 84, 69-73.

74. A. Karci, I. Arslan-Alaton, T. Olmez-Hanci and M. Bekbolet, Degradation and detoxification of industrially important phenol derivatives in water by direct UV-C photolysis and $\mathrm{H}_{2} \mathrm{O}_{2} / \mathrm{UV}$ C process: A comparative study, Chem. Engin. J., 2013, 224, 4-9.

75. Y. L. Sun, Q. Zhang, C. Anastasio and J. Sun, Insights into secondary organic aerosol formed via aqueous-phase reactions of phenolic compounds based on high resolution mass spectrometry, Atmos. Chem. Phys., 2010, 10, 4809-4822.

76. F. Barsotti, G. Ghigo and D. Vione, Computational assessment of the fluorescence emission of phenol oligomers: A possible insight into the fluorescence properties of humic-like substances (HULIS), J. Photochem. Photobiol. A: Chem., 2016, 315, 87-93.

77. E. De Laurentiis, V. Maurino, C. Minero, D. Vione, G. Mailhot and M. Brigante, Could triplet-sensitized transformation of phenolic compounds represent a source of fulvic-like substances in natural waters? Chemosphere, 2013, 90, 881-884.

78. T. D. H. Bugg, M. Ahmad, E. M. Hardiman and R. Rahmanpour, Pathways for degradation of lignin in bacteria and fungi, Nat. Prod. Rep., 2011, 28, 1883-1896.

79. Maurino, V., Borghesi, D., Vione, D. and C. Minero, Transformation of phenolic compounds upon UVA irradiation of anthraquinone-2-sulfonate, Photochem. Photobiol. Sci., 2008, 7, 321-327.

80. S. Berto, E. De Laurentiis, T. Tota, E. Chiavazza, P. G. Daniele, M. Minella, M. Isaia, M. Brigante and D. Vione, Properties of the humic-like material arising from the phototransformation of l-tyrosine, Sci. Total Environ., 2016, 545-546, 434-444.

81. S. Berto, E. De Laurentiis, C. Scapuzzi, E. Chiavazza, I. Corazzari, F. Turci, M. Minella, R. Buscaino, P. G. Daniele and Davide Vione, Phototransformation of L-tryptophan and formation of humic substances in water, Environ. Chem. Lett., 2018, 16, 1035-1041.

82. F. Barsotti, G. Ghigo, S. Berto and D. Vione, The nature of the light absorption and emission transitions of 4-hydroxybenzophenone in different solvents. A combined computational and experimental study, Photochem. Photobiol. Sci., 2017, 16, 527-538.

83. G. Ghigo, D. Vione and S. Berto, Experimental and theoretical study of the fluorescence emission of ferulic acid: Possible insights into the fluorescence properties of humic substances, Spectrochim. Acta A Mol. Biomol. Spectrosc., 2020, 228, article n. 117587. 
84. K. Komatsu, A. Imai and N. Kawasaki, Comparison between humic-like peaks in excitationemission matrix spectra and resin-fractionated humic substances in aquatic environments, Limnology, 2019, 20, 109-120.

85. X. Yang, J. Yuan, F.-J. Yue, S.-L. Li, B. Wang, M. Mohinuzzaman, Y. Liu, N. Senesi, X. Lao, L. Li, C.-Q. Liu, R. M. Ellam, D. Vione and K. M. G. Mostofa, New insights into mechanisms of sunlight- and dark-mediated high-temperature accelerated diurnal productiondegradation of fluorescent DOM in lake waters, Sci. Total Environ., 2021, 760, article n. 143377.

86. R. Del Vecchio and N. Blough, Photobleaching of chromophoric dissolved organic matter in natural waters: Kinetics and modeling, Mar. Chem., 2002, 78, 231-253.

87. A. Skoog, M. Wedborg and E. Fogelqvist, Photobleaching of fluorescence and the organic carbon concentration in a coastal environment, Mar. Chem., 1996, 55, 333-345.

88. R. J. Kieber, X. Zhou and K. Mopper, Formation of carbonyl compounds from UV-induced photodegradation of humic substances in natural waters: Fate of riverine carbon in the sea, Limnol. Oceanogr., 1990, 35, 1503-1515.

89. T. Brinkmann, D. Sartorius and F. H. Frimmel, Photobleaching of humic rich dissolved organic matter, Aquat. Sci., 2003, 65, 415-424.

90. S. E. Braslavsky, Glossary of terms used in photochemistry, $3^{\text {rd }}$ edition, Pure Appl. Chem., 2007, 79, 293-465.

91. Y. Zhang, X. Liu, C. L. Osburn, M. Wang, B. Qin and Y. Zhou, Photobleaching response of different sources of chromophoric dissolved organic matter exposed to natural solar radiation using absorption and excitation-emission matrix spectra, PLoS One, 2013, 8, article e77515.

92. W. He, I. Choi, J.-J. Lee and J. Hur, Coupling effects of abiotic and biotic factors on molecular composition of dissolved organic matter in a freshwater wetland, Sci. Total Environ., 2016, 48, 525-534.

93. J. Zumstein and J. Buffle, Circulation of pedogenic and aquagenic organic matter in an eutrophic lake, Water Res., 1989, 23, 229-239.

94. S. Hagemann, C. Chen, D. B. Clark, S. Folwell, S. N. Gosling, I. Haddeland, N. Hanasaki, J. Heinke, F. Ludwig, F. Voss and A. J. Wiltshire, Climate change impact on available water resources obtained using multiple global climate and hydrology models, Earth Syst. Dynam., 2013, 4, 129-144.

95. J. B. Butcher, D. Nover, T. E. Johnson and C. M. Clark, Sensitivity of lake thermal and mixing dynamics to climate change, Climatic Change, 2015, 129, 295-305. 
96. L. M. Mosley, Drought impacts on the water quality of freshwater systems; review and integration, Earth Sci. Rev., 2015, 140, 203-214.

97. R. G. Wetzel, Limnology: Lake and River Ecosystems, third ed. Academic Press, 2001.

98. S. C. Chapra, B. Boehlert, C. Fant, V. J. Bierman Jr., J. Henderson, D. Mills, D. M. L. Mas, L. Rennels, L. Jantarasami, J. Martinich, K. M. Strzepek and H. W. Paerl, Climate change impacts on harmful algal blooms in U.S. freshwaters: A screening-level assessment, Environ. Sci. Technol., 2017, 51, 8933-8943.

99. R. I. Woolway, S. Sharma, G. A. Weyhenmeyer, A. Debolskiy, M. Golub, D. Mercado-Bettín, M. Perroud, V. Stepanenko, Z. Tan, L. Grant, R. Ladwig, J. Mesman, T. N. Moore, T. Shatwell, I. Vanderkelen, J. A. Austin, C. L. DeGasperi, M. Dokulil, S. La Fuente, E. B. Mackay, S. G. Schladow, S. Watanabe, R. Marcé, D. C. Pierson, W. Thiery and E. Jennings, Phenological shifts in lake stratification under climate change, Nature Commun., 2021, 12, article n. 2318.

100. H. W. Paerl, and J. Huisman, Climate change: a catalyst for global expansion of harmful cyanobacterial blooms, Environ. Microbiol. Rep., 2009, 1, 27-37.

101. D. Vione and A. Scozzaro, Photochemistry of surface fresh waters in the framework of climate change, Environ. Sci. Technol., 2019, 53, 7945-7963.

102. K. E. Trenberth, A. Dai, R. M. Rasmussen and D. B. Parsons, The changing character of precipitation, Bull. Am. Meteorol. Soc., 2003, 84, 1205-1217.

103. M. H. I. Dore, Climate change and changes in global precipitation patterns: What do we know?, Environ. Intern., 2005, 31, 1167-1181.

104. K. E. Trenberth, Changes in precipitation with climate change, Clim. Res., 2011, 47, 123-138.

105. G. Myhre, K. Alterskjær, C. W. Stjern, Ø. Hodnebrog, L. Marelle, B. H. Samset, J. Sillmann, N. Schaller, E. Fischer, M. Schulz and A. Stohl, Frequency of extreme precipitation increases extensively with event rareness under global warming, Sci. Rep., 2019, 9, Article n. 16063.

106. A. Panton, F. Couceiro, G. R. Fones and D. A. Purdie, The impact of rainfall events, catchment characteristics and estuarine processes on the export of dissolved organic matter from two lowland rivers and their shared estuary, Sci. Total Environ., 2020, 735, article n. 139481.

107. P. J. A. Withers and E. I. Lord, Agricultural nutrient inputs to rivers and groundwaters in the UK: policy, environmental management and research needs, Sci. Total Environ., 2002, 282283, 9-24. 
108. M. N. Kolpakova and O. L. Gaskova, Major ions behaviour during evaporation of different saline type water of Western Mongolian lakes (geochemical modelling), Hydrol. Res., 2018, 49, 163-176.

109. E. A. Mohamed, A. M. El-Kammar, M. M.Yehia and H. S. Abu Salem, Hydrogeochemical evolution of inland lakes' water: A study of major element geochemistry in the Wadi El Raiyan depression, Egypt, J. Adv. Res., 2015, 6, 1031-1044.

110. L. M. Mosley, B. Zammit, E. Leyden, T. M. Heneker, M. R. Hipsey, D. Skinner and K. T. Aldridge, The impact of extreme low flows on the water quality of the Lower Murray River and Lakes (South Australia), Water Resour. Manag., 2012, 26, 3923-3946.

111. L. Carena, D. Terrenzio, L. M. Mosley, M. Toldo, M. Minella and D. Vione, Photochemical consequences of prolonged hydrological drought: A model assessment of the Lower Lakes of the Murray-Darling Basin (Southern Australia), Chemosphere, 2019, 236, article n. 124356. 